\title{
Transfer Pricing as Strategic Planning Tool for Multinational Enterprises in a Post-Isolation South Africa
}

\section{Petri Schutte}

Potchefstroom Business School, Potchefstroom University for Christian Higher Education

\section{Jozua Loots}

Tax Services, $K P M G$

\section{ABSTRACT}

Political and trade liberalisation leads to irrevocable change, exposing South Africa to the demands of the dynamic global market, driven by a deluge of competitive forces, demanding world-class, global competitiveness. The challenge facing South African organisations is to successfully transform in an economy undergoing structural change, moving away from import substitution to global competitiveness. Historically, stringent exchange controls prevented profits to emigrate from South Africa. Trade iberalization necessitates the introduction of transfer pricing legislation to protect the national tax base. Application of transfer pricing in practice is complex, information constraints compel the use of foreign comparables in determining a reward consistent with the arm's length standard, challenging objectiveness and risk adjustment. Strategic opportunities exist if transfer pricing is not entrenched in national regulation compliance.

JEL F23, M40

\section{INTRODUCTION}

Sanctions and trade embargos effectively isolated the South African economy from international markets. South Africa's economy prior to democratisation and trade liberalisation was predominantly geared towards import substitution. South Africa's re-entry into the international market must be seen within the context of expansion in international trade and commerce manifesting in wideranging changes in trade volume and complexity.

The latest UNCTAD ${ }^{\prime}$ World Investment Report (2000: 1) reports that transnational corporations (TNCs) totals 63000 parent firms with 690000 
foreign affiliates. These TNCs are involved in transactions that extend across virtually all countries impacting on all the economies they come into contact with.

The volume and mobility of international financial capital force governments of developing countries to adopt a conservative stance; economic policies are more restrictive with monetary and fiscal policy decision making at the core of achieving diminishing budget deficits along with single figure inflation targets.

Utmost care must be taken not to embark on a fiscal route that might tead to a decrease in investment in health, education, housing and infrastructure if measured in real terms. Funding such investment, governments must prevent erosion of their tax base. South Africa had stringent exchange controls that effectively prevented profits to emigrate. Trade liberalisation and relaxation of exchange controls forced the South African government to protect the South African tax base with transfer pricing and thin capitalisation provisions with the introduction in 1995 of Section 31 of the Income Tax Act.

Application of transfer pricing in practice is complex; information constraints necessitate the use of foreign comparables in determining a reward consistent with the arm's length principle. Use of foreign comparables challenge objectiveness and practical application relating to risk adjustment. Strategic opportunities exist if multinationals look beyond transfer pricing compliance and national regulations.

\section{INTERNATIONAL TRADE AND SOUTH AFRICA IN ISOLATION}

Since South Africa's return to active participation in global trade, struchural policy adjustment, economic growth and development strategies were embarked on in an attempt to increase global competitiveness of South African organisations.

World organisations established since the Second World War and the influence they have had on international trade as well as the trade policies they enforced, played a major role in South Africa's exclusion from intemational trade. International economies' increased integration in terms of banking and international finance drew national economies closer, resulting in the evolution of trade blocs during the late eighties and early nineties.

Economic sanctions, as South Africa experienced prior to 1994, have a major effect on the domestic economy. South Africa emerged from sanctions with 
artificially high domestic prices; an international trade vacuum existed and domestic manufacturing was geared towards import substitution.

The South African reaction to sanctions was domestic protection. Balassa (1972: 66) indicates that based on research done in developing countries ${ }^{2}$, protection tends to increase from lower to higher stages of fabrication. It seems that protection regimes follow the value chain of production. South Africa used tariffs and subsidies to substitute domestic production for imports and to balance domestic production and demand as far as possible. Since 1994 and under international agreements, tariff reduction in line with WTO bindings continues on route to lowering tariffs, following a tendency ${ }^{3}$ similar to the one reported by Balassa (1972: 71).

\section{POST-ISOLATION CHALLENGES AND COMPETITIVENESS}

The Reconstruction and Development Programme (RDP) the South African government embarked on since 1994 aims to create a better life for all and forms the central objective of economic policies. The Minister of Finance first presented the government's macro-economic strategy Growth Employment and Redistribution programme (GEAR) during the course of the Finance Budget vote on $14^{\text {th }}$ June 1996.

\section{Macroeconomic Strategy}

The objectives of the GEAR strategy were to move towards a competitive, outward-orientated economy. The following core element $s$ were to facilitate this:

Export led growth

Expansion of private sector capital formation

Accelerated private sector investment

Increased infrastructure development and

Improved labour intensive production.

Although the scenario projections gave a clear indication of expectations, it would have been prudent if cognisance was taken of the following realities:

Growth of at best 3 per cent per annum is expected.

With an optimistic economic growth rate, substantially higher spending on social services than was possible in the past is unlikely, given the reduction in the deficit of the budget.

Exchange rate volatility as experienced since February 1996 and the inherent danger of capital in- and outflows, add to the risk of a potential balance of payments crisis. Short-term adjustment in an event of rapid capital outflows must rest on monetary policy so that economic 
contraction and the resulting decline in import demand can be effectively managed.

The GEAR strategy does have flaws and with hindsight GEAR proved to be of value, providing a clear message of strategic intent.

\section{Industrial Strategy}

Historically South Africa was characterised by an industrial policy best described as import-substituting industrialisation. Import protection combined with import-substituting industrialisation led to a skewed concentration of economic ownership.

Protectionist policies were increasingly associated with inefficiencies (Balassa, 1972: 22), which led to stagnant economies, whose employment was threatened by lower cost producers in the global economy. Continuation of protectionist policies would have led to further stagnation and the persistence of inefficient production with diminishing formal employment.

The South African government made a deliberate attempt to move away from import-substituting industrialisation and sought to liberalise imports through encouraging exports and a shift from demand-side measures ${ }^{4}$ to supply-side measures $^{5}$ to stimulate the South African economy, in line with the GEAR strategy.

A formal programme of phased tariff reductions and tariff harmonisation commenced in 1995 in terms of the offer presented at the World Trade Organisation (WTO) in 1993. Although the tariff offer was based on consultation between business, labour and government, the reality was that average tariffs, maximum tariffs and the number of tariff lines decreased significantly. The Free Trade Agreement (FTA) between South Africa (SA) and the European Union (EU) became effective in 1999. Unfortunately, a multiplicity of supply-side programmes were introduced over a very short period of time, resulting in ineffective implementation due to a lack of coherence and vision. The full potential economic benefits of these policies therefore never materialised in South African.

\section{Globalisation and Competitiveness}

From an economic policy perspective, arguably the most significant development in recent times is the global extension of markets. Technology changes and global economic policies reduced barriers to the flows of goods and capital into Africa, which flows reached the $\$ 10$ billion $^{6}$ mark in 1999 , on the 
back of African governments actively seeking FDI through business friendly economic policies.

In 1999, the Clinton Administration re-launched the Africa Growth and Opportunity Act, now titled the Africa Trade and Development Act. At the Africa-European Union (EU) Summit held in Cairo during April 2000, emphasis was placed on integrating Africa into the world economy with Africa and the EU expressing a need to develop a strategic partnership:

... any serious reflection on the future of the world economy and therefore the living standards of the billions who inhabit our world, will show that a strategic shift towards a significantly larger world economy can only be achieved as a result of raising living standards in the countries of the South, and therefore the radical expansion of the world markets for capital, goods and services (Mbeki, 2000).

Joshi (1996:1) describes competitiveness as "the ability of a country to achieve sustained high rates of growth in the GDP per capita". Joshi also identifies identifies investment and saving as vital prerequisites, based on the premise that economic growth is driven by investment. Investment should be expanded to incorporate investment in the skills of people, acknowledging that people are the most important resource in the creation of wealth. Lambert (1997: 25) takes this argument further stating that training works, provided objectives are clearly set, learners know exactly what is expected from them and management understands how what is learned, will help achieving goals. Not enough can be done to increase South Africa's skills base, although the skills development levy may go some way to address the current skill shortage.

Sunter (1997: 11) states that to be a world-class company "you need to pass a written as well as an oral examination", with the written examination based on "financial statistics, growing real earnings per share (EPS) by five per cent per annum for ten years as well as offering the shareholders a total real return of at least ten percent for ten years, the so-called 5x10x10 rule". Schutte (1999: 1) defines competitiveness within the South African paradigm as the "ten golden rules of a competitive society":

Create a stable and predictable legislative environment.

Work on a flexible and resilient economic structure.

Invest in trade and technological infrastructure.

Promote private savings and domestic investment.

Develop aggressiveness on international markets as well as attractiveness for foreign value added industries.

Focus on quality and speed in the conduct of administration and reforms.

Maintain a relationship between wage levels, productivity and taxation 
- Preserve the social fabric by reducing wage disparity and strengthening the middle class.

- Invest in education, especially at secondary level and in the life long training and improvement of the workforce.

Balance the economy of globality and proximity to ensure wealth generation, maintain social cohesion and the value system."

\section{MULTINATIONAL ENTERPRISES}

Literature (Douglas \& Craig, 1989: 373, Hout et al., 1982:106, Levitt, 1983: 57 \& Salvatore, 1987; 307) suggests that the existence of multinational enterprises is initially driven by the competitive advantage provided by a global network of production and distribution. This is called a "multi domestic competitor" (Hout et al., 1982: 98) which later becomes a global organisation (Douglas \& Craig, 1989: 371, Hout et al., 1982: 106 and Levitt, 1983: 65).

Levitt (1983: 65) identifies two vectors that shape the world within this context, namely technology, a determinant of human preference and globalisation, an economic reality. Given the fact that commerce and business at large is about profit and wealth maximisation, the global company according to Levitt will "shape the vectors of technology and globalisation, pushing it towards convergence," which then become tangible as high quality, standardised products at an optimum price.

Douglas and Craig (1989: 384) state that initially, domestic competition and core competencies are extended internationally. However, they conclude that the ultimate goal is "maximal efficiencies in allocating of resources", confirming Levitt's view.

The multinational enterprise generates approximately \$9.5 trillion of global sales through foreign affiliates (UNCTAD, 1998: 1) with global exports by foreign affiliates at $\$ 2$ trillion. Gross product (UNCTAD, 2000: 1) associated with international production and foreign affiliate sales worldwide, increased faster than the total international production with sales reaching $\$ 14$ trillion towards the turn of the century, compared to $\$ 3$ trillion in 1980 .

Levitt (1983: 53) predicted that that the globalisation of markets is at hand with the end of the multinational as he sees it. In an article titled "How global companies win out" (Hout et al., 1982: 98) it is submitted that competition is changing in many industries, forcing international companies to change from being a "multi domestic competitor" to a global company. In this context, the global company attempts to exert leverage it might have, which ranges from 
cross national production scale economies to foreign competitors' cash flow resources through price competition.

National transfer pricing legislation might restrict price cuts insofar as it does not conform to the arm's length standard. In terms of South Africa's current regulations (South Africa, 1999: 12), these price cuts might be attributed to business strategies ${ }^{8}$ and as such the multinational might not be regarded as being involved in tax avoidance through transfer price manipulation.

National regulation should prevent internationalisation of cross border transactions to the extent that these transactions bypass national controls and scrutiny with proactive transfer pricing practices. Multinationals can use transfer pricing mechanisms based on connected party transactions to minimise tax exposure, depriving home or host economies from tax revenues.

Nations worldwide have instituted regulatory changes to attract investment as measured by FDI, in an attempt to reap the benefits from FDI investment. Cross border merger and acquisition activity is driven by companies' survival strategies in response to globalisation.

The annual growth rate of mergers and acquisitions (M \& A) of 35.4 per cent in 1999, indicates corporate strategy (UNCTAD, 2000: 14) recognising the effect of technological change, and changes in capital markets and regulatory environment (of which transfer pricing is one aspect). With mergers and acquisitions, corporations respond with strategies designed to expand current markets and explore new markets, increase market presence and consolidate market dominance, access to assets and proprietary assets and core competencies, financial opportunities and integration and diversification of risk. Over the short term, mergers and acquisitions might have small benefits for a developing country. The effect of mergers and acquisitions on the national economy is best described by the following:

Insofar investment capital inflow is not adding value to the current capital stock, it replaces only some existing capital and as such no additional capital is ploughed into the economy.

It is unlikely that new technologies will be transferred to developing economies on the back of a merger or acquisition. Vernon (1979: 199) and Lindert (1992: 107) indicate that when new technology is not crucial to comparative advantage of the corporation, it would migrate to countries that might have comparative advantage in other inputs such as labour.

It is unlikely that mergers and acquisitions will lead to job creation. The functions of the newly acquired member of the multinational might be extended, although certain functions might be performed centrally to eliminate duplication. 


\section{Multinational Enterprises and Transfer Pricing}

Salvatore (1987: 306) and Practice Note 7 (South Africa, 1999: 39) identify managerial expertise, technology, goods, parts and marketing intangibles as some of the goods and services that are transferred between the holding company and its foreign affiliate and on which the holding company expects a return. Within the transfer pricing paradigm, the return should be commensurate with the functions performed, assets used and the risk assumed by the various members of the multinational (South Africa, 1999: 34).

Exchange controls have historically provided some protection against the more significant manipulation of transfer prices to transfer profits to lower tax jurisdictions. In anticipation of the relaxation of exchange controls and the envisaged adverse effect on the South African tax base, section 31 was introduced into the Act in 1995. Section 31 enables the Commissioner to adjust the consideration in respect of a supply or acquisition of goods or services in terms of an international agreement between connected persons.

\section{Transfer Pricing}

The term transfer pricing describes the process by which entities set the prices at which they transfer goods or services between each other. The transfer prices adopted by a multinational have a direct bearing on the proportional profit it makes in each country it operates. If a non-market value is paid for the transfer of goods or services, the income attributed to each of the members of a multinational will be inconsistent with their relative economic contributions. This distortion will impact on the tax revenues and or tax liabilities in the relevant tax jurisdictions in which they operate.

The concept of transfer pricing does not imply anything complex; it is in essence a simple concept. However, the determination of transfer prices in practice can be very complex and measurement problems may arise, mainly due to information constraints relating to a South African comparable. Practice Note 7 and the OECD guidelines on the other hand, provide practical guidelines to taxpayers for determining arm's length transfer prices.

Although no statutory requirement has been placed on the South African taxpayer to document their respective transfer pricing practices, the need for documentation is evident from the approach the Commissioner will follow if such documentation does not exist. In view of the above, the taxpayer should make conscientious efforts to establish transfer prices that comply with the arm's length principle and prepare documentation ${ }^{10}$ to evidence such compliance. 


\section{Transfer Pricing Methodologies}

When selecting an arm's length transfer pricing methodology, taxpayers choose from those endorsed by SARS in Practice Note 7. Accordingly, the most appropriate method will be the one that produces the highest level of comparability based on facts and circumstances at hand, availability of data on which to base a comparability analysis and the nature and extent of any assumptions made in the study.

The most appropriate method is selected by testing comparability. The challenge is to obtain the most reliable measure of arm's length results. Practice Note 7(South Africa, 1999:10) ${ }^{11}$ states that the assessment of comparability can be affected by the characteristics of goods or services, relative importance of functions performed, terms and conditions of relevant agreements, relative risks assumed by the taxpayer, economic and market conditions and business strategies. The standard transfer pricing methods recognised by Practice Note 7 (South Africa, 1999: 17) are the comparable uncontrolled price method (CUP method), the resale price method (RP method), the cost plus method (CP method), the transactional net margin method (TNMM) and the profit split method.

Section 31 of the Act does not impose a hierarchy of transfer pricing methods. However, in effect a hierarchy exists in that certain methods might provide a more reliable result. Although the Commissioner acknowledges (South Africa 1999: 14) that the use of a particular method will depend on the facts on hand and that the most reliable method will be the method that requires the least adjustments to enhance comparability.

Testing the application of the various methodologies empirically, made apparent that methodology application is driven by the lack of comparable information publicly available in South Africa. The CUP method is hardly used at all, the resale price and cost plus methods are used if the transfer pricing practitioners have access to international databases such as Compustat. The transactional net margin method and the profit split methods are used, although the latter is used with a degree of subjectivity.

In terms of reliability, comparability and ease of application, to test if connected parties' dealings are at arm's length, it should be attempted to test as high as possible in the income statement. The potential negative effect operating expenses might have on comparability is limited to a large extent. 


\section{Figure 1 Transfer pricing methodologies comparison}

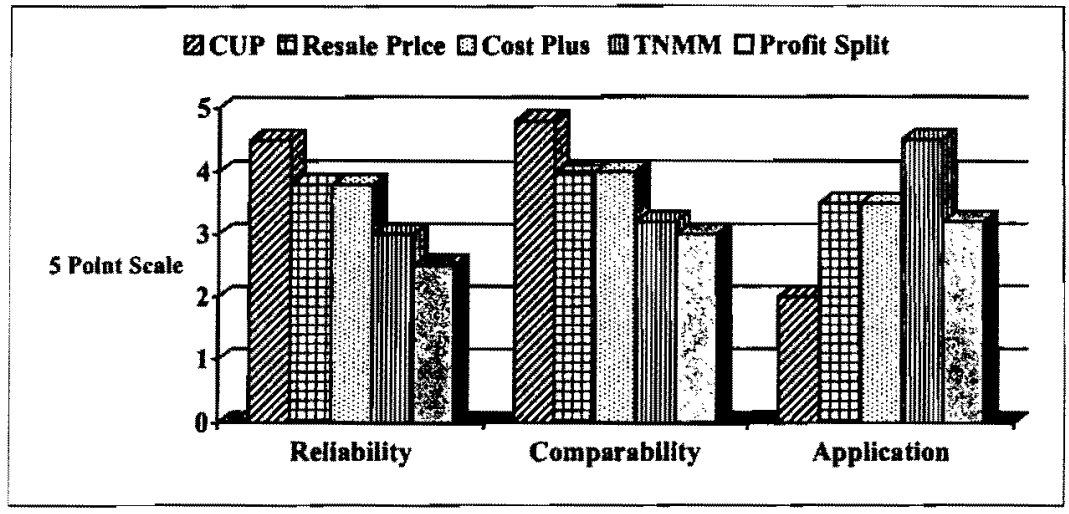

The CUP method is the most reliable and the method that requires the highest level of comparability, whereas the TNMM method's application is relatively easy compared to the CUP method.

\section{Transfer Pricing Practice}

In practice, the traditional methods such as the CUP, resale price and cost plus might prove almost impossible to apply, due to information constraints. The lack of comparable uncontrolled transactions and published gross margins data, make it necessary to resort to the transactional profits methods such as the transactional net margin and profit split methods.

The availability of data will probably determine methodology selection as South Africa is a relatively small economy and under certain circumstances reliable comparables may prove difficult, if not impossible to find. Applying a transfer pricing method to multiple comparable data after thorough consideration to the functions performed, assets used and risk assumed by the tested party should arrive at a result consistent with an arm's length outcome.

Criteria for the selection of comparable firms from independent databases are based on functional similarity; that is, the extent to which the functions undertaken are similar to the functions being investigated. Databases used to perform comparability research classify companies by Standard Industrial Classification (SIC) codes and allow a keyword search to be performed. In the study, the March 2001 version of Standard \& Poor's Research Insight (Compustat) (North American and Canadian) database was used. 
Comparability searches provide profit level information of comparable companies operating in different economies, in this instance, the US and Canada. Comparability would be negatively affected if knowledge of prevalent risk in the market was disregarded. Conceptualising national or sovereign risk within the transfer pricing context is not difficult. However, quantifying the difference in risk and making risk adjustments to the comparable dataset to enhance direct comparability, is complicated and requires a degree of subjective judgement.

\section{Risk Adjustment}

Various companies might be accepted on the basis of comparability. Profitability of comparable US companies should be adjusted by a country risk premium to enhance comparability. Using profitability level indicators of unadjusted US companies would be naïve and determining the arm's length range without due consideration of the perceived risks associated with investing capital in South Africa would certainly not enhance comparability.

The difference in risk between the US market and the South African market is considered the country risk premium. The profitability of the comparable US companies in addition to the country risk premium will provide a reliable measure of arm's-length result for companies conducting their operations in these countries.

Determining a risk adjustment premium is one aspect that complicates transfer pricing. Differences between inflation, short term interest rates and bond yields must be considered to provide for the market risk element within national economies. Multinationals' operations are diverse, functional activities stretch across industries, sectors and product ranges, and an approach must be found that accurately measures the risk-return trade-off and the effect diversification has on the actual rate of return.

The risk-return relation is often seen within the context of high returns associated with high risk. Alternative theories have been documented with the Bowman paradox (Kim et al., 1993: 275) postulating that companies with high returns can have low risk. Global market diversification provided companies with strategic options and opportunities (Kim et al., 1993: 276) beyond domestic companies and might explain the high retum low risk profile.

The approach followed in the study was based on testing the risk-return trade off on a stand-alone basis, extending the research to incorporate diversification across industry sectors and applying the stand-alone test of risk and diversification to a hypothetical South African company. The aim is to 
investigate the link between diversification strategies of the comparable datasets as identified during a multinational functional comparability analysis, as part of a transfer pricing study and their risk-return performance.

Following accepted practice in diversification research, company risk was measured by the standard deviation of ROA over the study period, 1995 to 2000 . The methodology used in determining the hypothetical risk adjustment is as follows:

i. Determine SIC codes applicable to identified functions to set parameters for comparable industry research.

ii. Query data sources (Compustat database used in this study) based on identified SIC codes to determine potential comparable companies to be used in the study.

iii. Select comparables based on independence, market level comparability and product similarities.

iv. Calculate ROA as comparable profit level (return) indicator.

$v$. Calculate industry risk as the standard deviation of ROA over the period under investigation. If this approach does not suffice, alternatives will be explored.

vi. Calculate weighted industry return of comparable companies based on the ratio of actual sales to total sales as determined by data analysis.

vii. Calculate the weighted industry risk by making use of the standard deviation based on ROA of the comparables for the period under investigation.

According to Kim et al. (1993: 275) the weighted industry risk is an appropriate measure of risk. Brigham et al. (1999: 172) state that in the determination of the risk in a portfolio context, the standard deviation of the portfolio, as a measure of portfolio risk, is generally not the weighted average of the standard deviation of the individual assets in the portfolio. The portfolio's standard deviation is generally smaller than the weighted average of the asset's standard deviation.

\section{Research Results}

The SIC codes used in the analysis were major groups 50 and 65 to test the diversity risk trade-off assumption. Both functions being tested are not assetintensive with plant, property and equipment ratio to sales less than 20 per cent. Undertaking the comparability search, 25 and 54 potentially comparable companies were identified. Screening measures to ensure comparability were based on independence, functional and product similarity.

From the ROA summary, there is a distinct difference in realised return between the two industry sectors. This difference (amount of spread) in realised returns 
within, as well as between the sectors, would be a good measure of the inherent risk within these industry sectors. Industry risk can be measured on a standalone basis by using the standard deviation of ROA within the industry sectors.

\section{Table 1 Standard deviation ROA}

\begin{tabular}{|l|c|c|c|c|c|c|}
\hline Industry sector & 1995 & 1996 & 1997 & 1998 & 1999 & $\mathbf{2 0 0 0}$ \\
\hline Major group 50 & $7.48 \%$ & $7.92 \%$ & $10.81 \%$ & $10.62 \%$ & $11.84 \%$ & $10.87 \%$ \\
\hline Major group 65 & $4.94 \%$ & $7.72 \%$ & $29.57 \%$ & $16.06 \%$ & $6.11 \%$ & $13.00 \%$ \\
\hline
\end{tabular}

Although the one industry sector is not discemably riskier than the other according to the standard deviation, on average major group 65 has the lower standard deviation and could be regarded not as risky as major group 50 .

The rate of return within portfolio context, is merely the weighted average rate of return for the specific year on the individual functions performed and assets used in terms of the portfolio. However, the risk of this hypothetical portfolio is not the weighted average of the standard deviation of the individual functions being performed in the portfolio. The portfolio's standard deviation will probably be smaller than the weighted average standard deviation of the assets in the portfolio.

Functions' rate of return might move counter cyclically to each other. Measuring this tendency of functions' return could be achieved by making use of the correlation coefficient $r$. In reality, whilst performing various functions, it would be unlikely that the different functions would be perfectly positively correlated. However, positive correlation exists and on average, combining positively correlated functions in a portfolio sense, would reduce risk but would certainly not eliminate it. It can be deduced that some risk remains even with diversification, but the risk might be smaller than it would be if the functions were seen in isolation.

An amount of risk can be eliminated; the diversifiable risk can be managed. However, the remaining portion of risk, market risk, stems from factors that influence all participants in the economy including war, recessions, inflation and interest rates.

It is apparent that investors demand a premium for assuming risk. Within the context of transfer pricing, risk should not be regarded functionally on a standalone basis, but rather within the wider context of operations where the company performs various functions, each exposed to a different level of risk. 
Two industry sectors were identified; returns and industry risk were tested for each. Major group 65 realised lower returns and was exposed to lower industry risk measured by the standard deviation on a stand-alone basis.

This illustrates the risk-return assumption on a stand-alone basis. Making use of a weighting scale based on functional sales' contribution to total sales of the two functions performed by the business units in different industry sectors would allow for an analysis of the risk-return and industry diversification.

A similar approach to the one followed testing the risk-return relationship in a stand-alone basis will be followed to determine a hypothetical risk adjustment factor. First, the weighted industry return of a company that diversified into industry sectors 50 and 65 was tested and second, the weighted industry risk is measured to get a better understanding of the diversification effect across industry on risk.

Table 2 Weighted industry ROA and standard deviation

\begin{tabular}{|l|c|c|c|c|c|c|}
\hline & 1995 & 1996 & 1997 & 1998 & 1999 & 2000 \\
\hline Diversified - ROA UnAdiu & 0.171747 & 0.146965 & 0.175535 & 0.144309 & 0.107208 & 0.109946 \\
\hline Diversified - Sd Dev $_{\text {ROA }}$ & 0.086190 & 0.017524 & 0.015518 & 0.016278 & 0.027360 & 0.029241 \\
\hline $\begin{array}{l}\text { Major Group 50 ROA } \\
\text { Major Group 65 ROA }\end{array}$ & 0.194052 & 0.147440 & 0.143167 & 0.126420 & 0.092178 & 0.091886 \\
\hline $\begin{array}{l}\text { Major Group 50 }-S^{\text {td }} \text { Dev } \\
\text { ROA }\end{array}$ & 0.074754 & 0.079222 & 0.108122 & 0.106243 & 0.118376 & 0.10869 \\
\hline $\begin{array}{l}\text { Major Group 65 }-S^{\text {td }} \text { Dev } \\
\text { ROA }\end{array}$ & 0.049445 & 0.077236 & 0.295725 & 0.160551 & 0.061135 & 0.129973 \\
\hline
\end{tabular}

From the summary in Table 2 it seems as if the assumption that overall risk can be diminished compared to stand-alone risk of the industry when diversifying across industries, is founded. The study does not explore the extent to which this is true. In 1997 risk was reduced considerably in a weighted industry perspective compared to the stand-alone risk as measured by the standard deviation of major group 50 of 10.81 per cent and 29.5 per cent of major group 65 respectively.

\section{Application in Practice}

It can be assumed that a relationship exists between risk and return and by diversifying across industry sectors and potentially national markets, risk can be minimised leaving the company exposed to market risk, which the company cannot diversify from and is completely out of its control. 
For the purpose of this study it is essential to determine a single measure of risk that can be used in adjusting returns to enhance comparability from a transfer pricing perspective. The approach being followed is in essence based on the determination of a return premium to compensate for the risk assumed. To achieve the objective of determining a single measure of risk-adjusted return, an approach that incorporates a return premium based on a unit of risk was followed.

Table 3 Risk adjustment premium

\begin{tabular}{|c|c|c|c|c|c|c|}
\hline Kisk & 1995 & 1996 & 1997 & 1998 & 1999 & 2000 \\
\hline omparab & 0.09902 & & & & 0.08865 & 0.09725 \\
\hline & & 965 & & & 0.10 & \\
\hline$S^{\text {td }} \mathrm{De}$ & 0.08619 & 0.017524 & & 78 & 0.02736 & 0.02924 \\
\hline $\mathrm{ROA}_{\mathrm{Sar}}$ & & & & & & \\
\hline $\mathrm{K}_{\text {Risk Free }}$ & 0.075 & 0.07 & & & 0.05 & 0.075 \\
\hline Mean & & & & & & \\
\hline Retur & 0.072729 & 0.0 & & & 0.063 & 5209 \\
\hline Retur & & 0.965284 & 0.545455 & & 0.678258 & 0.43408 \\
\hline
\end{tabular}

A single risk premium adjustment factor was calculated between a hypothetical South African company with subsidiaries performing functions comparable to companies operating in major industry sectors, major groups 50 and 65 . The risk premiums are calculated between the hypothetical South African company and the comparable companies operating in the US as substantially different, driven predominantly by government bond yield rates, risk free.

Another approach to measure a risk premium, is to extend the current approach by making use of the capital asset pricing model (CAPM), a tool for analysing the risk return relationship. The CAPM model from a transfer pricing perspective is based on the premise that the relevant riskiness of an individual function, is its contribution to the risk of a well-diversified portfolio of functions being performed. Performing a specific function in isolation might be regarded as very risky; however, some of the risk could be eliminated by diversification so that the function's relevant risk is much smaller than its stand-alone risk being evaluated in isolation (contribution to functional portfolio risk).

It is clear that the risk remaining after diversification is market risk, which could be measured by the degree to which a function's return tends to follow the movement of the market in which the function is being performed. The tendency of a share (an asset) to move up and down with the market is reflected 
in its beta coefficient, $\beta$. Beta is central to the CAPM model as used to analyse the relationship between risk and rates of return (measured by the beta coefficient).

A function exposed to average risk, using assets, is the one whose rate of return or return on investment, tends to move up or down in line with the general market or industry in which it may perform, the general market's returns being a measured by an index. The index will by definition have a beta value of 1.0 .

Within a transfer pricing context, comparable companies are selected because they are functionally similar to the tested party. The companies selected are companies passing qualitative and quantitative measures where independence and sufficient sales information are usually prerequisites. Under the CAPM theory beta is an appropriate measure of an asset's relevant risk. The rate of return, the compensation for the investor for assuming this risk at a specific beta value, must be in line with the investment risk, this premium being the market risk premium. The beta coefficients calculated for the two industry sectors are a reflection of the relative risk return relationship and are shown in Table 4.

\section{Table 4 Beta coefficients}

\begin{tabular}{|c|c|c|c|c|c|c|}
\hline Beta co & 1995 & 1996 & 1997 & 1998 & 1999 & 2000 \\
\hline Major group 50 - Beta & 0.8970181 & 1.017362 & 1.064128 & 1.066771 & 1.049574 & \begin{tabular}{|l|l|}
4 & 1.059386 \\
\end{tabular} \\
\hline Majo & & & & & & \\
\hline Beta portfolio & & & & & & \\
\hline \multicolumn{7}{|l|}{ Standard deviation } \\
\hline Major group $50-S^{\text {td }}$ Dev $R O A$ & & 0.079222 & & 0.106243 & & $6 \quad 0.108690$ \\
\hline Aajor group $65 \cdot S^{\text {Ld }}$ Dev ${ }_{\text {ROA }}$ & 0.049445 & 0.077236 & 0.295725 & 0.160551 & 0.061135 & $\begin{array}{ll}5 & 0.129973 \\
\end{array}$ \\
\hline $\begin{array}{l}\text { tandard dev, portfo } \\
\text { ontext, formula } 11\end{array}$ & & 0.10518 & 0.245198 & 0.140413 & 0.060441 & $1 \mid 0.119674$ \\
\hline
\end{tabular}

From this table Major Group 50 has greater total risk except in 1997, 1998 and 2000. However, using the calculated beta coefficients, another picture emerges. Major Group 65 may have greater total risk in some years, i.e. 1997, but over the period under investigation, it was exposed to considerably less systematic or market risk than Major Group 50 (beta coefficient was lower than that of Major Group 50).

Since total risk is the sum of market and diversifiable risk, Major Group 50 must have a higher risk premium and greater rate of return despite the fact that sometimes it might have less total risk. Factoring risk into rate of return implies that the rate of return should be equal to risk free return and the risk premium. 
The risk premium adjustment calculated, is in essence hypothetical and considerable research must be done to find a methodology that can be applied to accurately capture the differences in comparability when undertaking a transfer pricing analysis. Information constraints in developing economies complicate the determination of an arm's length price or profit level indicator to derive a result that is consistent with the arm's length standard.

\section{FACTORS DRIVING TRANSFER PRICING POLICY}

There are no statutory requirements in South Africa that compel local enterprises to document or even conduct a transfer pricing study. However, in responding to questions on the IT 14 tax return, the public officer must be cautious not to omit material facts relating to transfer pricing that might be construed as non-disclosure of material facts.

\section{Transfer Pricing and Strategic Planning}

\section{Transnational life cycle hypothesis and technology diffusion}

The transnational life cycle hypothesis is primarily based on the international product life cycle theory of Vernon (1966: 195) and the product cycle hypothesis in a new international environment (Vernon, 1979: 261).

Functions that multinationals or their subsidiaries perform can be broadly classified as exportation, distribution, manufacturing, global operations and market exit. Based on these broad categories, transfer pricing is seen within the transnational life cycle hypothesis model.

The transnational life cycle hypothesis on which the study is based might incorrectly give the impression that it predicts the transnationality behaviour of companies. It must be noted that the transnational life cycle hypothesis does not imply that companies progress from left to right on the life cycle. Various factors would determine the relative position of a company on the life cycle curve.

Certain functional activities might be suspended or outsourced; others might be included in the business portfolio, making it naïve to construe that companies will start exporting, then distribute, manufacture, etc. This phenomenon of company movement between different stages of the life cycle, may be attributed to technology diffusion, technology being one factor that drives companies' relative positioning on the life cycle model. Cross border merger and 
acquisition statistics indicate that technology is one of the drivers of global environment changes.

Technology will give a company a comparative advantage as long as the technology is an integral part of the company's core competency. Vernon (1966: 196) expressed the view that once a product became more standardised it became less apparent that it should be produced in the country where the comparative advantage initially existed. Bringing this dimension of technology diffusion into the transnational life cycle hypothesis model makes it clear that technology diffusion would to a certain extent drive functionality within the transfer pricing context.

\section{Figure 2 Transnational life cycle hypothesis model}

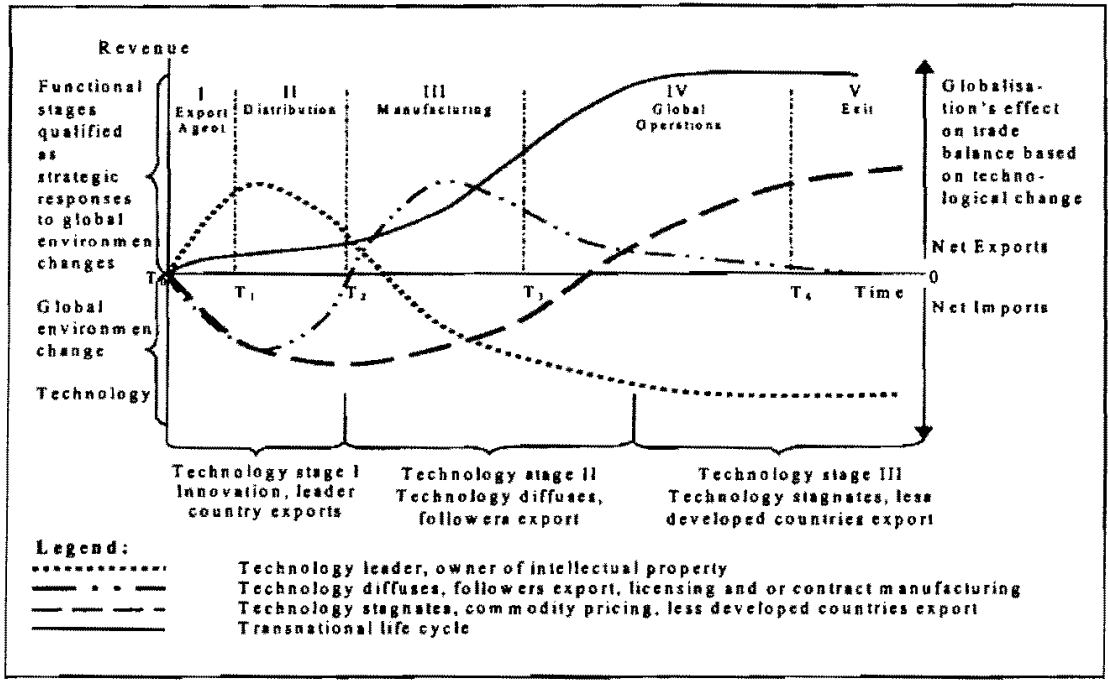

Source: Adapted from Vernon 1966: 199

At $\mathrm{T}_{0}$ the technology leader would export new products based on this new technology. The other technology-advanced nations would import the product, design and develop similar technologies and products, even through subsidiaries of the original inventor. The technology leader would typically export, and distribute through its own network of subsidiaries and permanent establishments or branches.

At technology stage II, the technology is not sufficient to maintain its comparative advantage; technology would most probably be licensed to contract manufacturers in developed industrial countries. The technology would diffuse 
further with developing countries obtaining the rights to the technology and its products.

This confirms the trends identified if FDI flows as published by UNCTAD are seen within this hypothetical model. FDI flows are predominantly between developed countries with the developing economies being involved predominantly in asset swaps.

Discussion and research relating to international strategies tend to focus on the initial stages of entry into international markets (Douglas et al., 1989: 367). However, within this study and the transfer pricing paradigm, the focus would be on strategies extending beyond mere initial international market entrance.

\section{Global strategic dynamics}

In the determination of the potential direction of future growth, cost of expansion into new national economies, should be seen within the context of globalisation, diminishing international trade barriers and world competitiveness. Strategic issues and imperatives would naturally to a large extent depend on the magnitude of corporate learning as well as the nature of current operations in international markets.

Propositions of Vernon and the Hechscher-Ohlin theory in essence identify phases in the internalisation or globalisation process based on production location and production factor endowment. Surely, more than this must be driving globalisation. Douglas (1989: 368) proposes that strategy formulation is driven by the intermationalisation phase the company finds itself in. Within the context of the transnational life cycle model, this proposition of Douglas surely seems to be the foundation of strategic intent.

Explicit strategy formulation within the global market is crucial. First, it would establish objectives regarding the level of activity or operational presence to a specific market. Second, the level of involvement in a specific market would be indicative of the degree of risk the company is prepared to assume with careful consideration of the risk-return trade-off and diversification across national boundaries and industry sectors. This approach would encompass systematic evaluation of strategic opportunities globally. 


\section{Figure 3 Dynamics of global strategy development}

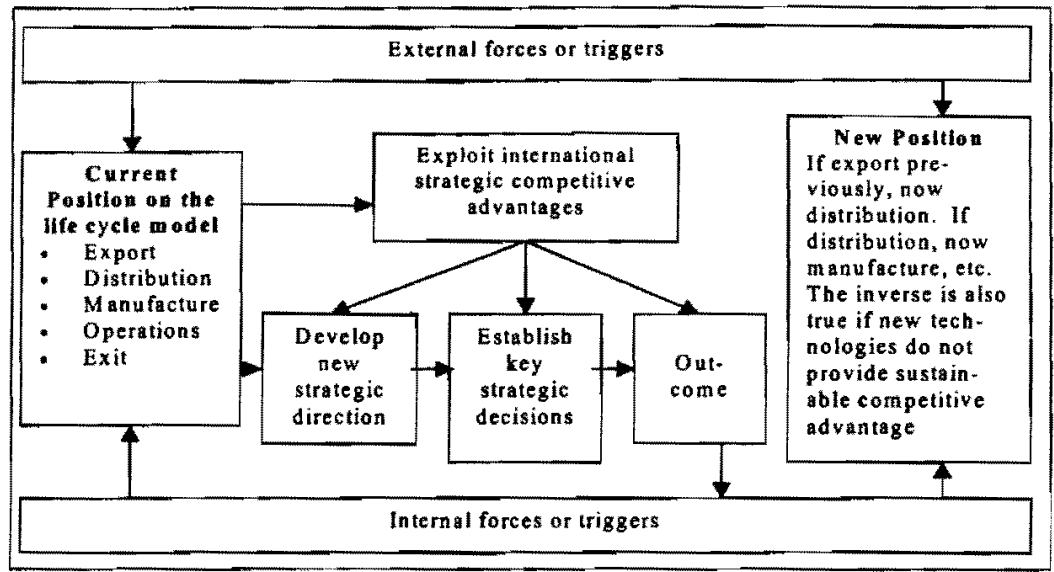

The dynamics of global strategic development is based on the various phases as identified in the transnational life cycle hypothesis model. External and internal forces act as triggers that would prompt development into a new stage or phase. This then generates new strategic direction, feeding into key strategic decisions that have a specific outcome, which in turn will be influenced by external and internal forces. Combined, these forces will define investment and resource allocation priorities depending on the stage in which the company is, i.e. distribution or manufacturing; each would have its own priorities within the broader framework.

Essentially, key strategic decisions and expected outcomes will be driven by the various internal and external factors within each functionality stage. External triggers would include environmental factors, industry trends and prevalent industry competitive forces whereas internal triggers might be declining sales volumes and profitability. No specific research was undertaken to determine what these triggers might be although experience in undertaking transfer pricing analysis on a functionality basis confirms the abovementioned assumptions.

\section{Compliance and Strategy}

\section{Transfer pricing compliance}

Preparation of documentation in response to a SARS query is the main focus and priority of transfer pricing. Performance and management bonuses as well as planning to maximise value chain operations are not very significant. The 
status quo might be attributed to the fact that most participants are subsidiaries of transnational organisations with the strategic planning being done offshore.

Transfer pricing activity is predominantly driven by compliance. This is in accordance with the transnational life cycle hypothesis model, which indicates that a subsidiary that predominantly performs agency, distribution and to a limited extend manufacturing on behalf of their international principal focuses on legislative compliance.

Regulatory actu ity is currently focused on information gathering. Information is predominantly sourced from taxpayers by making use of questionnaires. The questionnaires cover a range of transactions with the pricing of intangible property not being directly investigated.

International tax issues over and above transfer pricing being regarded as important confirm the current compliance focus. Customs duties and value added taxation (VAT) were highlighted as current issues and the perception prevails that customs duties would remain an important issue in future.

There is a relation between compliance and strategic opportunities. The transnational life cycle hypothesis model draws a comparison between the product life cycle and technology diffusion, with the transnational company's life cycle being determined functionally and by technology maturity. Within this proposition, the transnational must comply with national legislation and subsequent to compliance, strategic responses result in strategic opportunities as illustrated.

Within the framework of the following model, the South African subsidiary is predominantly concerned with compliance. However, from a transnational perspective, there is clearly a compliance strategic planning continuum.

Initially compliance would be the main force driving strategic planning, but with the transnational organisation being forced by global change driven by technology, capital market reform and national regulatory change, strategic responses must follow the global market stimuli. If a company fails to respond, it would fall prey to merger and acquisition or being threatened by market exit. 


\section{Figure 4 Strategic planning and compliance}

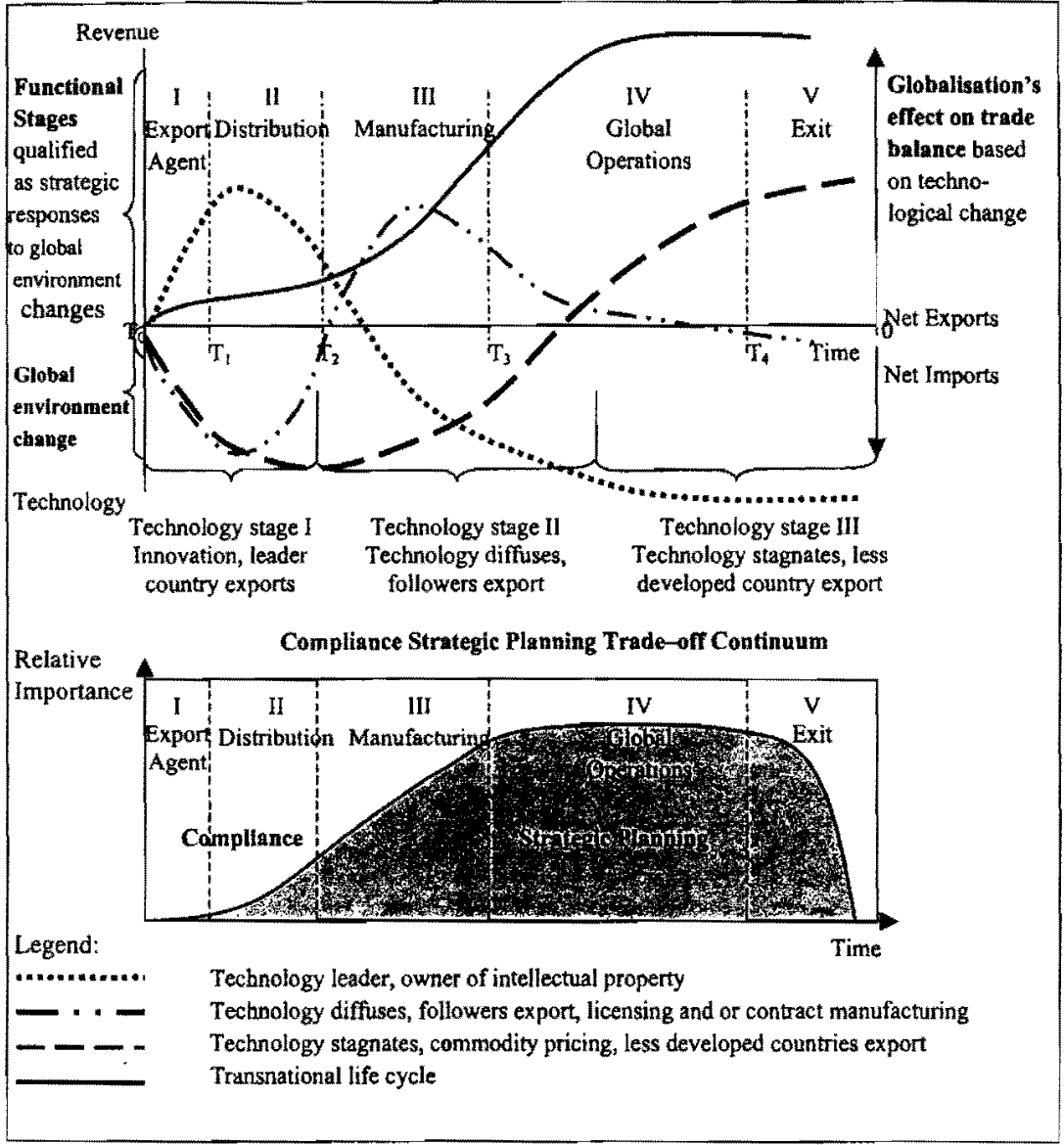

Within this context, an industry's strategic responses to changes in the global environment were investigated. Responses will differ from industry to industry; however, looking at the responses on a generic level would indicate a general direction it would follow and cannot be regarded as industry specific.

\section{Strategic responses}

Strategic responses of the chemical industry were investigated in broad terms. On an industry-specific basis some of the major trends that are impacting on and driving global competitiveness in the industry are: 
- Slower growth can trigger a change of strategic direction and focus with cross industry diversification becoming attractive options. Global production is expected to grow by only 4.3 per cent by 2003 .

- The chemical industry is shifting from its concentrated dependence on tonnage petrochemicals and inorganics, to new business based on performance and service. More than 90 per cent of all chemicals bought are for use in other industries.

- Environmental and toxological regulatory changes are having a major impact on the industry at large. The regulatory issues include the Basel Convention on the Control of Transboundary Movements of Hazardous Wastes and their Disposal (1989); the Montreal Protocol on Substances that Deplete the Ozone Layer (1987), the 1992 Rio de Janeiro United Nations Conference on Environment and Development and the Koyoto Protocol on the emission of greenhouse gasses (1997).

In response to these broad trends, strategic responses of chemical companies are a result of:

- Internationalisation and globalisation of markets, which topics are covered in the study.

- Consolidation of mature businesses and merger and acquisition activity that increased from 75 deals in 1999 to 83 in 2000, valued at more than US\$ 25 million.

- Ensuring a realistic balance between capital, R\&D, production and functions.

- Relocating offshore from a strong home base as suggested by Vernon (1966: 199) as technology matures.

- Diversification in "downstream" businesses.

- Building large enterprises from diverse niche businesses in line with globalisation trends to become true transnational organisations as proposed by the transnational life cycle hypothesis model.

- Developing strategies for each niche.

- A shift towards decentralised niche type organisation structures.

Strategic opportunities closely associated with participation in global markets and broader industry diversification are based on:

Global market diversification provides for potential benefits associated with economies of scale and scope (Levitt, 1983: 57) over and above the potential of mere product diversification.

Different nations have different factor endowments and as such in the absence of efficient markets the difference in factor costs (Lindert, 1991: 594) would provide cost advantages for global, diversified companies by configuring their value added chain. The value added chain can be 
configured per country to the extent of utilising the most overall cost efficient production advantage.

- In essence, global market diversification creates opportunities to increase potential retums by spreading activities across multiple global markets without necessarily committing resources to potentially higher risk activities.

- Competitive retaliation (Hout et al., 1982: 98) that could come from various national bases, might effectively limit domestic competitors' strategic options. It would be unlikely that domestic competitors would be able to effectively erode the multinational's competitive position.

Operations in multiple markets minimise adverse economic shocks on profitability that might be driven by specific national economic circumstances. Production and or value adding activities can be shifted around the world.

Multinational operations are not as vulnerable to national supply and demand conditions prevalent in specific national economies as would be the case if it were operating solely from a domestic base (stand-alone basis). In effect, the supply and demand risk is greatly diminished.

Transfer pricing in essence tests functions performed to obtain a result consistent with the arm's length principle, taking into account the assets used and risk assumed in performing such functions. Within this context the importance of strategic planning based on risk diversification is of immense value.

\section{CONCLUSION}

From the study it is apparent that countries benefit from international trade. South Africa came from isolation with relatively high domestic prices and stringent exchange controls that effectively prevented any international profits from leaving the country.

With South Africa's integration into world markets, rapid trade liberalisation followed with dire consequences for South African organisations that were not as competitive as their international competitors. The South African Government made brave attempts to alleviate the consequences of the structural adjustments the South African economy was exposed to. Although intent from government's intent was to enhance South African competitiveness, execution of the various policies and programmes was uncoordinated and lacked vision.

The regulatory framework changed dramatically with transfer pricing being incorporated in the Tax Act in 1995 to prevent erosion of the South African tax 
base to erode by transferring profits out of South Africa. Since 1995 and until 1999 when Practice Note 7 was released, enforcement of the legislation was not priority. Currently the approach has changed, companies are requested to provide details about their transfer-pricing practices and to document their dealings with related parties offshore.

Documenting transfer-pricing practices in accordance with the transfer-pricing guidelines presents a new challenge. Information that could be used in transferpricing analysis relating to South African companies is inadequate. This lack of information prompts the use of foreign comparables in transfer pricing studies while creating its own problems, like comparability and objectiveness, whilst undertaking a transfer-pricing study.

Time will tell what the SARS would accept as current practice in determining transfer prices that are consistent with the arm's length standard, especially comparability issues like risk adjustment, that may enhance comparability if foreign comparables are being used.

South African companies in general see transfer pricing as a regulatory compliance exercise. However, as South African companies are becoming global players in the true sense, transfer-pricing practices may prove to become a gauge and a tool for global strategic pricing opportunities.

\section{ENDNOTES}

1 United Nations Conference on Trade and Development.

2 Research was done in Brazil, Chile, Mexico, Malaysia, Pakistan, Norway and the Philippines.

3 Tariffs for certain steel coil is at 5 per cent whereas tariffs for certain electronic components can be as high as 20 per cent with further reductions in tariffs in the foreseeable future.

4 Policies such as import controls, tariffs, subsidies and General Export Incentive Scheme (GEIS).

5 Policies to stimulate the economy on the supply side, aimed at reducing costs and the efficient use of inputs.

UNCTAD Press Release; TAD/INF/2857.

7 Multidomestic competitors within the text are regarded as a competitor that allows individual subsidiaries to compete independently in different domestic markets.

$8 \quad$ Practice Note 7 paragraph 8.5 . 
9 Inadequate or excessive consideration, based on economic analysis which determines an arm's length reward based on the functions performed, assets used and risk assumed.

10 Sections 69, 74, 74A, 74B, 74C, 74D and 75 of the Income Tax Act 1962 deals with SARS' right to documentation for the purposes of administering the Act and these provisions are applicable to transfer pricing.

11 Practice Note 7, paragraph 8.2.1.

\section{REFERENCES}

1 BALASSA, B. (1972) The Structure of Protection in Developing Countries, Upper Saddle, New Jersey: Prentice-Hall.

2 BRIGHAM, E.F., GAPENSKI, L.C. \& EHRHARDT, M.C. (1999) Financial Management. Theory and Practice, $\left(9^{\text {th }}\right.$ ed.) Ford Worth, Texas: The Dryden Press: 1087.

3 CAMPBELL, H. (1999) "Africa Trade Bill Position. US Partnership or Domination of Africa: Reflections on the discussions over the Africa Growth and Opportunity Bill", [Available on Internet:] http://aidc.org.za/archives/agop_brc.html [Date of use: July 12]. CHAN KIM W., HWANG P. \& BURGERS W.P. (1993) "Multinationals' Diversification and the Risk-Return Tradeoff", Strategic Management Journal, 14: 275-85.

5 DOUGLAS, S.P. \& CRAIG, C.S. (1989) Evolution of Global Marketing Strategy: Scale, Scope and Synergy", In Enis, B.M., Cox, K.K., Mokwa, M.P., Marketing Classics. A selection of Influential Articles, $\left(8^{\text {th }}\right.$ ed.) Upper Saddle, New Jersey: Prentice-Hall: 279-85.

6 HOUT T., PORTER M.E. \& RUDDEN E. (1982) "How Global Companies Win Out", Harvard Business Review 60(5): 98-108.

7 JOSHI, S.K. (1996) "International Competitiveness Revisited" Eko-Info, $4(6)$.

8 LAMBERT, T. (1997) "Global Competitiveness: Advantage Comes with People Development" HRM Yearbook: 24-25.

9 LAMBKIN, M. \& DAY, G.S. (1989) "Evolutionary Processes in Competitive Markets: Beyond the Product Life Cycle", in Enis, B.M., Cox, K.K., Mokwa, M.P. Marketing Classics. A Selection of Influential Articles, $\left(8^{\text {th }}\right.$ ed.) Upper Saddle, New Jersey: Prentice-Hall: 447-67.

10 LEVITT, T. (1983) "The Globalization of Markets", In Enis, B.M., Cox, K.K., Mokwa, M.P., Marketing Classics. A Selection of Influential Articles, ( $8^{\text {th }}$ ed.) Upper Saddle, New Jersey: Prentice-Hall: 53-65.

11 LINDERT, P.H. (1991) International Economics, $\left(9^{\text {th }}\right.$ ed.) Burr Ridge, Illinois: IRWIN: 682. 
12 MBEKI, T. (2000) "Integrating Africa into the World Economy", (Statement at the Africa European Union Summit on 4 April 2000.) Cairo: 5. [Available on Internet:] http://www.anc.org.za/ancdocs/history/mbeki/2000/tm0404.html [Date of use: July 7$]$.

13 SACTU (South African Congress of Trade Unions) An injury to one is an injury to all. [Available on Internet:]

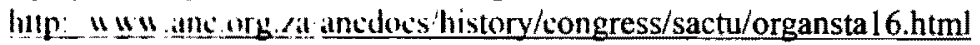
[Date of use: July 12]

14 SALVATORE. D. (1987) Intornational Economics, $\left(2^{\text {nd }}\right.$ ed.) New York, New York: The Macmillan Press Ltd: 610.

15 SCAMMELL, W.M. (1974) International Trade and Payments, London, Great Britain: The Macmillan Press Ltd: 607.

16 SCHUTTE, P.C. (1999) "Global Competitiveness: Ten Golden Rules of a Competitive Society", (Lecture on 9 October 1999 as part of the Managerial Economics course of the MBA.) Potchefstroom: Potchefstroom Business School.

17 SMALLWOOD, J.E. (1973) "The Product Life Cycle: A Key to Strategic Marketing Planning", In Enis, B.M., Cox, K.K., Mokwa, M.P., Marketing Classics. A Selection of Influential Articles ( $8^{\text {th }} \mathrm{ed}$.) Upper Saddle, New Jersey: Prentice-Hall: 438-45.

18 SOUTH AFRICA. (1999) "Practice Note 7. Section 31 of the Income Tax Act 1962: Determination of the taxable income of certain persons from international transactions: Transfer Pricing. Pretoria: Government Press.

19 SUNTER, C. (1997) What it Really Takes to Be World Class, Cape Town: Human \& Rousseau Tafelberg: 186.

20 UNCTAD (United Nations Conference on Trade and Development) (1998) Overview. World Investment Report 1998: Trends and Determinants. [Available on Internet:]

http://www.unctad.org./en/docs/wir98ove,en.pdf [Date of use: June 15].

21 UNCTAD (United Nations Conference on Trade and Development) (2000) "Overview. World Investment Report 2000: Cross-border Merger and Acquisitions and Development", [Available on Internet:] http://www.unctad.org./en/docs/wir00ove.en.pdf [Date of use: July 08].

22 UNCTAD (United Nations Conference on Trade and Development) (2000) "Survival in Global Business Arena is Key Driver of Cross-Border Merger and Acquisition Boom, UNCTAD Press Release TAD/INF/2855 [Date of press release: Oct 03].

23 UNCTAD (United Nations Conference on Trade and Development) (2000) "FDI to Africa Rises in 1999, but Continent must Become Bigger Market Player, Says UNCTAD Report", UNCTAD Press Release TAD/INF/2857 [Date of press release: Oct 03]. 
24 UNCTAD (United Nations Conference on Trade and Development) (2000) "Global Foreign Direct Investment to Exceed \$1 Trillion, UNCTAD Predicts", UNCTAD Press Release TAD/INF/2856 [Date of press release: Oct 03 ].

25 VERNON, R.G. (1966) "International Investment and International Trade in the Product Cycle", Quarterly Joumal of Economics, 80(2): 199-207.

26 VERNON, R.G. (1979) "The Product Cycle Hypothesis in a New International Environment", Oxford bulletin of Economics and Statistics, No. $41: 255-67$ November.

27 WEST, R.L. (1975) "Economic Dependence and Policy in Developing Countries", In Bergsten, C.F., Tyler, W.G. Leading Issues in International Economic Policy, Lexington, Massachusetts: Lexington Books: 157-84. 